\section{INHIBITION OF FOCUS FORMATION OF RAT CELLS BY MOUSE SARCOMA VIRUS BY DAMAVARICIN FC DERIVATIVES}

Sir:

Streptovaricins were discovered by SiminofF et al. and have been studied for their potential antitubercular activity ${ }^{1)}$. A chemical study of streptovaricins was made by RINEHART and his colaborators and the relationship between chemical structure and biological activity was explored $^{2)}$. In addition to antibacterial activity, inhibition of reverse transcriptase of RNA tumour virus was observed in streptovaricins ${ }^{3)}$. There is evidence that streptovaricins block the transformation of mouse cells by MoLONEY murine sarcoma-leukemia complex in vitro ${ }^{4}$.

We have been interested in the various kinds of damavaricin $\mathrm{C}$ (DvC) derivatives which have been derived from streptovaricin $\mathrm{C}(\mathrm{SvC})$ as reported previously ${ }^{5)}$. DvC has a newly formed phenolic hydroxyl group at the C-19 position of the naphthoquinone ring in the molecule, thus enabling us to prepare various derivatives having an alkyl ether linkage at this position. Thus obtained DvC derivatives retain their antibacterial activity, but acquire cell killing activity for mammalian cells, including viral transformed cells and human leukemia cells, in vitro ${ }^{6)}$. Because of their cell killing activity, DvC derivatives have not yet been examined for an intriguing property, that is the inhibition of focus formation by RNA tumour virus.

During the course of the preparation of DvC by treatment of SvC with oxygenated concentrated ammonia - methanol (1:2), at the same time was produced "damavaricin Fc" (DvFc, 1) which was found to be an atropisomeric mixture of two compounds, damavaricin Fc (1a) and atropisodamavaricin $\mathrm{Fc}(\mathbf{1 b})^{7)}$, at a ratio of $1: 3$ $\left[\mathrm{C}_{36} \mathrm{H}_{43} \mathrm{NO}_{12}, \operatorname{mp} 224 \sim 226^{\circ} \mathrm{C},[\alpha]_{\mathrm{D}}^{30}-532^{\circ}(c\right.$ $\left.0.11, \mathrm{CHCl}_{3}\right)$, the fact having been suggested from the peak intensities of the two phenolic hydroxyl protons in the pmr spectrum (unpublished data). Damavaricin Fc (1a), in which the ansa bridge lies above the aromatic nucleus, has the $\mathrm{P}$ helicity as well as natural streptovaricins, whereas atropisodamavaricin Fc (1b), in which the ansa bridge lies below the aromatic nucleus, has the M helicity as shown in Fig. 1. To avoid complicating nomenclature, hereafter we will use DvFc to refer to the atropisomeric mixture of damavaricin Fc. DvFc (1) has a $\delta$-lactone ring between $\mathrm{C}-7$ and $\mathrm{C}-10$ of the ansa bridge which has been proved to produce a change in one of the biological properties. Specifically, the loss of antibacterial activity implies that DvFc has lost its capacity to bind RNA polymerase of prokaryotic cells. The inhibitory activity of the reverse transcriptase, however, is retained. These observations have prompted us to prepare various derivatives of DvFc as well as DvC and to examine their biological activity. DvFc has also an additional phenolic hydroxyl group at the C-19 position of the naphthoquinone ring, enabling the derivatization at this position as shown in Fig. 1.

It is of interest that DvFc derivatives are less toxic against animal cells in vitro as compared with DvC derivatives. Therefore we were able to test whether or not any of the derivatives inhibited focus formation by MSV/MLV complex. As shown in Table 1, methyl (2), ethyl (3), and $n$-pentyl (4) ethers of DvFc were effective, whereas benzyl ether (7) was not effective.

Fig. 1.

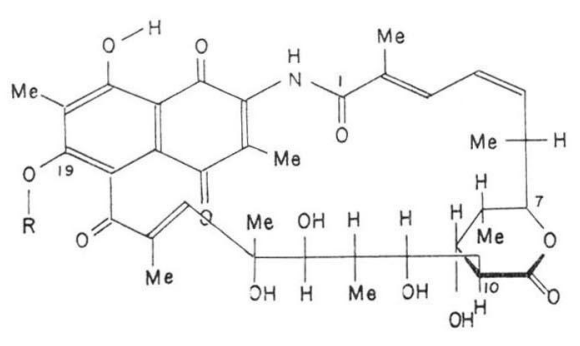

Ia $(R=H)$

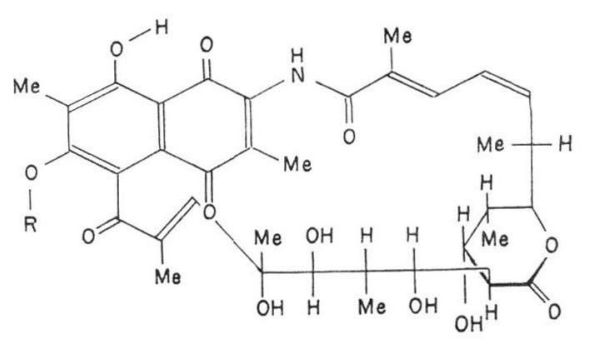

Ib $(R=H)$

$R=2:$ Methyl 3: Ethyl 4: n-Pentyl

5: $n$-Hexyl

6: $n$-Undecyl

7: Benzyl 
Table 1. Inhibition of focus formation by MSV/MLV and inhibition of RDDP.

\begin{tabular}{|c|c|c|c|}
\hline DvFc derivative & $\begin{array}{r}\% \text { Inhibition } \\
\text { focus } \\
\text { focus }\end{array}$ & $\begin{array}{l}\text { at } 5 \mu \mathrm{g} / \mathrm{ml} \\
\text { drug } \\
\text { drug }\end{array}$ & $\begin{array}{c}\% \text { Inhibition of } \\
\text { RDDP at } 30 \mu \mathrm{g} / \mathrm{ml}\end{array}$ \\
\hline 2 & $76 / 111$ & $28.2 \%$ & 56 \\
\hline 3 & $39 / 59$ & $20 \%$ & 34 \\
\hline 4 & $64 / 111$ & $42.3 \%$ & 60 \\
\hline 7 & $48 / 51$ & $6.0 \%$ & 0 \\
\hline
\end{tabular}

NRK cells were grown to $1.5 \times 10^{5}$ cells/dish in $20 \mathrm{~cm}^{2}$ Falcon Petri dishes in EAGLE's MEM supplemented with $10 \%$ fetal calf serum and $10 \%$ tryptose phosphate broth.

Cells were infected with MoLoneY's mouse sarcoma virus and Polybrene was added to a final concentration of $2 \mu \mathrm{g} / \mathrm{ml}$. At the same time the derivatives were added at a concentration of $5 \mu \mathrm{g} / \mathrm{ml}$. After three days' incubation, the medium was removed and the fresh medium was added. After further three diays' incubation, the cells were fixed and stained. The activity of reverse transcriptase was measured as follows. The reaction mixture in a final volume of $0.1 \mathrm{ml}$ containing: $0.03 \mathrm{M}$ Tris- $\mathrm{HCl}$ buffer ( $\mathrm{pH} 8.1$ ); $0.024 \mathrm{M} \mathrm{KCl} ; 0.01 \mathrm{M} \mathrm{MnCl}_{2} ; 0.5 \times 10^{-3} \mathrm{M}$ dATP, dCTP, dGTP; $0.025 \%$ NP40; 5 mM dithiothreitol; $7.5 \mathrm{~mm}\left[{ }^{3} \mathrm{H}\right]$-dTTP (New England Nuclear Corp., $1 \mathrm{Ci} / \mathrm{mol}$ ). Samples were incubated at $37^{\circ} \mathrm{C}$ for 60 minutes and the reaction was terminated by addition of $1 \mathrm{ml}$ of cold $10 \%$ trichloroacetic acid (TCA). The precipitate were then washed extensively with cold $5 \%$ TCA on "Millipore" filters, cried and counted in a liquid scintillation counter. DvFc derivatives were dissolved in methanol at a concentration of $6 \mathrm{mg} / \mathrm{ml}$.

Table 2. Inhibition of the growth of mouse leukemia virus.

\begin{tabular}{|c|c|c|c|c|c|}
\hline \multirow{2}{*}{ Exp. } & \multirow{2}{*}{ Drug } & \multirow{2}{*}{$\begin{array}{l}\text { Concentration } \\
(\mu \mathrm{g} / \mathrm{ml})\end{array}$} & \multirow{2}{*}{$\begin{array}{l}\text { Cell No./dish } \\
\left(\times 10^{6}\right)\end{array}$} & \multicolumn{2}{|c|}{ Relative activity } \\
\hline & & & & c.p.m. & $\%$ \\
\hline \multirow[t]{2}{*}{ I } & no drug & - & 2.9 & 2972 & 100 \\
\hline & 4 & 5 & 1.6 & 87 & 2.9 \\
\hline \multirow[t]{2}{*}{ II } & no drug & - & 4.8 & 3920 & 100 \\
\hline & 4 & 3 & 4.3 & 180 & 4.6 \\
\hline \multirow[t]{5}{*}{ III } & no drug & - & 4.4 & 3784 & 100 \\
\hline & 1 & 4 & 4.2 & 3917 & 104 \\
\hline & 2 & 5 & 4.9 & 2773 & 73 \\
\hline & 5 & 4 & 4.5 & 2689 & 71 \\
\hline & 6 & 5 & 4.4 & 3784 & 100 \\
\hline
\end{tabular}

NRK cells were grown to $1.5 \times 10^{5}$ cells/dish as described in the legend to Table 1 . Cells were infected with MOLONEY mouse leukemia virus. After four days' incubation, the culture fluid was collected by centrifugation at 25,000 r.p.m. overnight. The white band which formed at the density of 1.159 was collected and resuspended in TEN buffer. The RDDP activity of the obtained viruses was measured as described in the legend to Table 1.

It is noteworthy that the inhibitory activity of the derivatives for the reverse transcriptase (RDDP) in vitro was related to their inhibitory activity on focus formation by mouse sarcoma and mouse leukemia virus complex.

Next, the effect of the derivatives on the growth of nouse leukemia virus was examined. Normal rat cells were infected by mouse leukemia virus. After four days, the virions were collected from the culture fluid by centrifugation and the growth of leukemia virus was compared by measuring the activity of the reverse transcriptase in the virions. As shown in Table 2, the derivatives used in this experiment were not toxic against cell growth, but the growth of the virus-infected cells was slightly inhibited. Al- 
though methyl (2), n-hexyl (5), n-undecyl (6) ethers and DvFc itself did not inhibit viral growth, $n$-pentyl ether (4) did. The hydrophobic groups introduced into $\mathrm{C}-19$ position of $\mathrm{DvFc}$ seem to confer the properties of penetrability and selectivity for the cells.

It has been reported that the inhibitory activity of the streptovaricins for reverse transcriptase in vitro is weak compared with rifamycin ${ }^{8,8,9,10)}$. Results of in vivo experiments using streptovaricins in the past, however, were very interesting. It was reported that the growth of mouse mammary tumours was significantly inhibited by the oral administration of streptovaricin complex ${ }^{11)}$ and that the oral administration of streptovaricin complex reduced RAUSCHER leukemia virus induced splenomegaly ${ }^{12}$.

In this context, we believe it is worthwhile to study the DvFc derivatives in vivo. Fortunately the acute toxicity of the DvFc derivatives is remarkably reduced compared with streptovaricin or damavaricin $\mathrm{C}$ derivatives (unpublished data). Experiments along this line are in progress now.

\section{KAZUKIYO ONODERA}

Institute for Virus Research, Kyoto University, Sakyo-ku, Kyoto 606, Japan

\section{AkIYoshi HiRagun \\ MaYumi Sato \\ Hiromi MitsuI}

Tokyo Metropolitan Institute of Medical Science, Bunkyo-ku, Tokyo 113, Japan

\section{KaZUYa SASAKI*}

Central Research Laboratories, Kaken Chemical Co., Ltd., Bunkyo-ku, Tokyo 113, Japan

(Received March 8, 1979)

\section{References}

1) Siminoff, P.; R. M. Smith, W. T. Sokolski \& G. M. Savage: Streptovaricin. I. Discovery and biological activity. Am. Rev. Tuberc. Pulm. Dis. $75: 576 \sim 582,1957$

* To whom correspondence should be addressed.
2) Rinehart, Jr., K. L.; M. L. Maheshwari, K. Sasaki, R. J. Schacht, H. H. Mathur \& F. J. Antosz: Chemistry of streptovaricins. VIII. Structures of streptovaricins A, B, D, E, F, and G. J. Am. Chem. Soc. 93: 6273 6274, 1971

3) Rinehart, Jr., K. L.; F. J. Antosz, K. Sasaki, P. K. Martin, M. L. Maheshwari, F. Reusser, L. H. Li, D. Moran \& P. F. Wiley: Relative biological activities of individual streptovaricins and streptovaricin acetates. Biochemistry 13: $861 \sim 867,1974$

4) Carter, W. A.; W. W. Brockman \& E. C. Borden: Streptovaricins inhibit focus formation by MSV (MLV) complex. Nature, New Biol. 232: $212 \sim 214,1971$

5) Onodera, K.; Y. Aor \& K. Sasaki: Inhibition of tumor cell growth in vitro by damavaricin $\mathrm{C}$ derivatives. Agr. Biol. Chem. 40: 1381 1385, 1976

6) Onodera, K.; K. SASAKI, Y. Yamamoto, Y. Nishikawa, A. Hiragun \& H. Mitsur: Growth inhibition of human lymphoid cells in vitro by damavaricin $\mathrm{C}$ derivatives. Agr. Biol. Chem., submitted.

7) Rinehart, Jr., K. L.; F. J. Antosz, D. V. Deshmukh, K. Kakinuma, P. K. Martin, B. I. MilaVetZ, K. SASAKi \& T. R. Witty: Identification and preparation of damavaricins, biologically active precursors of streptovaricins. J. Antibiotics 29: $201 \sim 203,1976$

8) Gurgo, C.; R. K. Ray, L. Thiry \& M. Green: Inhibitions of the RNA and DNA dependent polymerase activities of RNA tumor viruses. Nature, New Biol. 229: 111 114, 1971

9) Gurgo, C.; R. K. Ray \& M. Green: Rifamycin derivatives strongly inhibiting RNA-DNA polymerase (reverse transcriptase) of murine sarcoma viruses. J. Natl. Cancer Inst. 49: 61 79, 1972

10) Tischler, A. N.; U. R. Joss, F. M. Thomspon \& M. Calvin: Synthesis of some rifamycin derivatives as inhibitors of an RNA-instructed DNA polymerase function. J. Med. Chem. 16: $1071 \sim 1075,1973$

11) Kramarski, B. \& W. J. Manthey: Inhibition of growth of mouse carcinoma by streptovaricin. Proc. Soc. Exp. Biol. Med. 145: 1434 1439, 1974

12) Borden, E. C.; W. W. Brockman \& W. A. CARTER: Selective inhibition by streptovaricin of splenomegaly induced Rauscher leukemia by virus. Nature 232: $214 \sim 216,1971$ 